\title{
Gender differences in occupational wage mobility in the 1958 cohort.
}

\begin{abstract}
This paper examines the wage growth of British men and women between the ages of 33 and 42 who were employed full time at both of these ages using the 1958 National Child and Development Study. Wage growth is examined in the differences of the log of hourly wage rates reported at the 33 and 42 year old interviews of this cohort study. Men were found to have higher wage growth rewards than women when in higher occupations and be more likely than women to be in these higher wage growth occupations. Women's wages grew more slowly over the period than men's wages because they were located disproportionately in lower growth and feminised jobs. Domestic ties did not explain the differences in wage growth for this group, where the occupational penalties of gender widened.
\end{abstract}

KEY WORDS. Gender. Mobility. Occupations. Wages. 1958 Birth cohort

\section{Introduction}

Men and women are known to have different wage rates in the labour market of most European countries. Although the gender wage gap has been declining over time, it has not gone away (Kingsmill, 2001, Women and Work Commission, 2006). The difference between rates of pay remains between women in part-time jobs and men in full-time jobs, and within the full-time labour force, which features in headline measurements of the pay gap. Equality seems more elusive among workers in mid-life than in their twenties. It is tempting to draw the conclusion that unequal pay is being phased out, and will disappear as the younger generation grows older, the 'cohort replacement' theory. However, this conclusion would be premature. It is important to understand how far the pay gap among mature workers in full-time employment is to be explained by women at these ages having less earning power than men, for example, if they have less continuous employment records or fewer qualifications, and how far the labour market is remunerating equivalent characteristics unequally. But since successive generations of women are gaining more education and work experience, it is also important to examine whether the economic logic of human capital theory will drive out gender inequality, or whether social norms, gendered expectations and choices and labour market career structures will continue to hold back equality between men and women. The focus of this paper is on whether 
and how a key group of employees, born in 1958, fared as they moved across their thirties. Of course, this 1958 cohort, aged 42 at the turn of the new Millennium, do not represent all women currently in the labour market in the first decade of the $21^{\text {st }}$ century. However, they are an interesting group who were among the first to benefit from Statutory Maternity Leave and other anti sex discrimination legislation enacted in the 1970s which gave them greater opportunities to accumulate human capital. This group give us pointers about what we can expect for subsequent generations.

Previous analysis of the 1958 cohort data (Joshi et al 2007) found that for the admittedly select group of workers who had been in full-time employment at both age 33 and age 42 surveys, the relative pay of men and women grew wider. The cohort replacement theory would predict this gap would remain constant over time (variation would be between cohorts, not along the life course within them). Women employed full time at both these ages were found to experience increasingly unequal treatment, given their human capital. ${ }^{1}$

This paper takes up the story by focusing on the wage growth of these employees observed twice, and looking beyond human capital characteristics to other work-related and home-related contexts of these trajectories to try to understand why women's pay fell behind, even for a group where one might least expect it to.

Real wage growth can occur in a number of ways - through remaining in one occupation, and possibly moving up set salary scales, by changing job within the same occupation, or changing job and occupation. Individuals who move jobs may have more potential to improve their wages and experience wage growth. However, they may also suffer slow wage growth or even wage decline. Occupational change can be thought of as a route through which the accumulation of human capital is rewarded, or failure to maintain it is penalized. Particularly in the face of gendered occupational segregation, it is pertinent to enquire if these rewards and penalties affect men and women equally. Most analyses of the gender wage gap have focused on explaining the different wage levels, often at a point in time. However, an analysis of wage growth incorporates a more dynamic element into the explanations of gender wage gaps.

In the rest of this paper we review the existing literature on the gender wage gap (Section 2). In section 3 we outline our model. Section 4 describes the available data. Section 5 discusses the results and our conclusions are presented finally in Section 6. 


\section{Earlier studies - explaining the gap.}

It is important to examine how far work-related or home-related experiences are responsible for gender wage differentials. Typically women's lower levels of employment participation and greater time spent in unpaid work in the home, even when they are also in paid jobs, are potential explanations of wage differentials. Wage gaps would be expected to result where men had more of the favourable market characteristics than women; where men were rewarded more favourably for their market characteristics than women; or when men were disproportionately located or segregated in jobs which pay high rates. Existing wage differences underpin partnered men continuing to accumulate more market characteristics since it is then more economic for lower paid partnered women to be the ones to carry out care within the home while higher paid men continue to be employed. However, different preferences and aspirations of men and women to do paid work or care for the family can also underpin the different gendered attachments to paid and unpaid work. Men being rewarded more favourably than women can be partly due to men and women being segregated into different jobs and career paths or pay scales within the same broad occupation groups, or through direct discrimination taking place. Evidence for all of these potential contributors to the wage gap can be found in the literature. However, the balance of factors may change over time if men's and women's earning attributes change over time, or if the rates at which they are remunerated diverge over time. The latter may come about through differential access to the most remunerative career pathways.

A series of studies have attempted to understand the size and causes of the gap in wages between employed men and women. Zabalza and Arrufat (1986) suggested that the gender gap could mainly be attributed to women who interrupted their employment histories for 'home time', (which they imputed on the basis of children born), giving women less experience than men in paid work. However, Wright and Ermisch (1991), analysing actual employment histories of married men and women in the Women and Employment Survey, found unequal remuneration for education and experience also contributed to the pay gap, as did low pay in part-time jobs (Ermisch and Wright, 1993; Manning and Petrongolo, 2004). Joshi and Paci (1998) found unequal remuneration for human capital between male and female full timers, and between women working full and part time. Part-time jobs have mostly been low skilled, low paid jobs in services or retail and many studies have documented the problem of downward occupational mobility among women who took up part-time work after childbirth (Grant et al, 2005). 
Other authors introduced further information to account for gender wage differences, for example, training, travel to work distances, firm size, and unionization differences. These all help to account statistically for the wage gap (Anderson, 2001; Joshi and Paci,1998; Paci et al, 1995). In addition, the extent of occupational segregation in the jobs held by men and women also explains a part of the gap. It is also supposed that occupational segregation keeps women's wages low even for full-timers, in that it is more difficult to implement the 1986 Equal Pay for Equal Value legislation where there are few male comparators. When segregation is recorded at the level of the workplace, there is some evidence of a pay penalty to working in a feminized workplace (Millward and Woodland 1995). Hakim (1998) concluded that vertical sex segregation is much more important than horizontal segregation across occupations, accounting for around three quarters of the gender earnings differential. This implies that women's earnings were held back more by their failure to make occupational advances than by their choice of, or selection into, stereotypically female types of job on entry to the labour market. However, it is difficult to disentangle the pay penalty attached to working part time from the low status of jobs which have hitherto been offered on a part-time basis.

A worker's family position may be a relevant factor in generating pay differentials, but it is not clear exactly what the relationship may be. On the one hand, responsibility for supporting children, elders or a spouse may give a worker more incentive to work productively. The employer may recognize or even encourage a breadwinning role by offering a 'family wage', and the 'dependents' may actually, through their non-market inputs, enhance the worker's productivity. On the other hand, family responsibilities may detract from productivity, be perceived as making workers less reliable or motivated, may reduce bargaining power in the labour market, confine the worker to low paid part-time work or lead to intermittent employment experience. It is also possible that people in a given family status happen to have high or low wages for other reasons. High earners may find it easier to find and keep a spouse for example. Greater family responsibilities have tended to be associated with higher wages for men (Akerloff, 1998) and lower wages for women, mirroring and possibly reinforcing, gender differences in family roles. Joshi and Paci (1998) failed to find much direct impact of motherhood on women's pay after allowing for its indirect effects through work experience and part-time employment. However, when models of the pay gap which do not control for family responsibilities find an unexplained gap between men's and women's pay, one reason may be the asymmetrical effects on wages of family responsibilities and particularly unpaid work commitments in the home. Women in all industrialized countries do far more unpaid domestic 
work in the home than men, even when they also engage in paid work (Gershuny, 2000). The gender pay gap has also been found to vary across ages and across the wage distribution (Arulampalan et al, 2006), being higher at the top and bottom ends of the distribution, and it exists even when graduates only are considered as early as 7 years after graduation (Purcell and Elias, 2008).

In principle, wage changes within the same employer (or occupation) can enhance wages where there is an internal career ladder. However, it is also possible to progress a career by changing jobs. It is even possible to gain promotion within the same job by getting an outside offer and using it to lever a pay rise in the current job by using the threat of leaving. Booth and Francesconi (1999) reported that among full-timers remaining in the labour force over a 5-year period, men and women had remarkably, and surprisingly, similar chances of promotion. This would appear to suggest that women full-timers were indeed breaking through the glass ceiling, though there is some doubt about how well promotions are identified in the data. Booth and colleagues (2003) then pointed out that women were nevertheless at some disadvantage, as they had higher chances of quitting and gained less wage growth between the rungs of the promotion ladder than the men, a 'sticky floor'. They also conjectured, though they could not directly observe, that women's slower wage growth may be due to being less aggressive or less risk taking in the job market. Blackaby et al (2005) found women academic economists were less likely than men to receive outside offers, to gain from them if they received them, or to be promoted. The pattern of slower career progression for women employed full time also applies in many other occupations (Crompton and Sanderson, 1990). Manning's (1996) drew attention to the importance of monopsony in the setting of low wages for women. Whether such unequal treatment is 'unfair' or discriminatory is another question. Recent papers by Manning and Swaffield,( 2006) and Joshi et al (2007) both find that the faster growth of men's wages over the first two decades of labour force years cannot just be explained by men accumulating more employment experience. This finding forms the starting point of the current investigation.

Existing evidence on gender wage gaps points to human capital playing a part in explaining the gap, from the amount of time women and men spend in paid work, but it by no means explains all of the gap. Earlier studies point to the need to consider potential gender differences in other work-related career opportunities and career paths. It is also important to consider gendered choices of occupations and employer's gendered expectations since these are both maintained by social norms and underpin occupational segregation and internal career ladders in the workplace. Lastly, gender differences in amounts of unpaid domestic work in the home should 
ideally be taken into consideration, which have an economic logic, once wage differentials come into being, as well as being subject to social norms.

\section{Model}

Current wages at time t are expected to reflect earlier accumulation of an individual's human capital (Becker, 1975; Mincer, 1974) from educational qualifications achieved through schooling, work experience and training. Periods out of work are expected to have caused depreciation of the stock of human capital up to that point, as well as halting its accumulation, leading to subsequent declines in the potential wages of those who have been out of the labour market.

There have been a number of discussions and debates about gender differences in human capital accumulation (Dex, 1985). Women, as reviewed above, tend to have lower wage rates than men and in part at least, this is due to different earlier investments in human capital. Wage growth became part of the early debates over whether women expected to have time out of the labour market to have children and consequently invested less in human capital as result. Another alternative, suggested by Mincer and Polachek (1974), was that women would select an occupation bearing in mind their expectations to leave the labour market for a time, and choose occupations that incurred lower penalties (depreciation rates) for time out of work. The issue this raised was that it took for granted a slower rate of wage growth on returning to work after a labour market gap. What if there was a faster rate of wage growth, big enough for women to recoup the losses due to labour market absence? Some evidence emerged to support the idea that wage growth was faster after returns to work (Dex, 1985). However, over time, behaviour has changed quite substantially. Educational qualifications have equalized among young men and women, occupational choices have moved to be more similar, although far from being identical, work experience has not equalized although some women's gaps out of work for childbirth have drastically reduced, and wages have grown closer (particularly for younger workers). The precise characteristics of our particular surviving samples of men and women born in 1958 are described in Section 4 below.

We focus in this paper on the period from age 33 to 42 and examine wage growth of full-time employed men and women over this 9 year period. Individuals' wage rates at age 33 embody their past human capital investments up to that point. An examination of wage growth controls for any differences between gender groups up to the starting point by differencing the starting 
wage from the end wage. The inclusion of origin occupations, correlated with educational attainment, is one way the model also allows for any additional advantaged gained from having a certain level of human capital at the outset, age 33.

A number of possible measures of wage growth were considered and the measure we adopted was felt to be the best option for these hourly wage data over this period, which have a very long upper tail and given wage rises are mostly calculated in percentage rather than absolute terms. We selected, therefore, the log of the ratio of the end wage over the starting wage.

Our main approach to examining wage growth differences of men and women was to model the difference in log wages, LN (W), between two points in time, age 33 (time t-1) and 42 (time t) as follows:

$L N\left(W_{t} / W_{t-1}\right)=a_{1}+\sum^{k} \beta_{k}\left(X_{k t}-X_{k t-1}\right)+\sum_{Y_{j}}^{j} Z_{j t-1}+\varepsilon$

Where $X$ is a vector of $k$ characteristics that change over the period from $t-1$ to $t$, with associated coefficients $\beta$, and $Z$ is a vector of $j$ characteristics, with associated coefficients, $\gamma$, that represent the initial conditions at the start of the period. This approach is closer to offering a linear model with Gaussian errors which can be estimated with OLS regression. The log specification depresses the effect of outliers, although several extreme outliers were already removed from the data.

Our independent variables were chosen to reflect the concerns found in the literature. Clearly human capital measures have dominated the explanations of wages, but do not adequately explain all of the gender wage gap. We were interested in adding in measures of gender occupational segregation, career structures, career paths and other work-related explanations as well as home-related behaviours, attitudes and preferences. For the independent variables, $\mathrm{Z}$, attached to the start of the period, $\mathrm{t}-1$, we were mindful that using the wage difference as our dependent variable would already have controlled for the obvious human capital determinants of wage levels up to the start of the period. None the less, we considered it likely or possible, given occupation by age trajectories, that certain occupations (and possibly education levels) might have different wage growth paths because they offer different career trajectories and 
imply certain levels of gender occupational segregation. In addition, since high earners, overlapping with high occupations, are often able to command higher pay rises, we needed to capture this phenomenon. We included occupation codes at $\mathrm{t}-1$ as dummies, therefore, to capture these effects. ${ }^{2}$ We included an additional indicator of whether the occupation was mainly dominated by women, men or integrated across men and women (the reference group was mainly female dominated). ${ }^{3}$ The home-based explanations associated with the start of the period including living with a partner or having dependent children at base year (as two dummy values). Stereotyped expectations here would be that having a partner and having a dependent child at $\mathrm{t}-1$ would each motivate men to gain more promotion and wage growth, whereas they may impede women from pursuing their career.

For independent variables, $\mathrm{X}$, indicating change from time $\mathrm{t}-1$ to time $\mathrm{t}$, we included, as workrelated measures, the depletion of human capital over the period by having two dummy variables capturing any periods out of employment, and dummy variables for having an additional training spells of 3 days or more, gaining an additional educational qualification, or having a spell of part-time work. Other work-related variables included dummy variables to indicate whether there had been changes in occupations and/or jobs, and whether it was a male, female of integrated occupation (using 3 digit 1990 SOC occupation codes), in order to capture some of the earlier findings in the literature reviewed above about the occupational segregation and potential differences in men's and women's career paths.

Our data on job changes did not contain information about whether individuals stayed with the same employer. However, we consider that changes of occupation category are most likely to indicate a change of employer. We included, therefore, a dummy variable for an upward change in occupation, and one for downward occupational change, from the origin occupation at time t1 to the destination occupation at time t. A third dummy indicated the individual reported a job change over the period, but no occupation change. The occupational ranking for upward or downward moves from age 33 to age 42 was derived from 9 SOC major 1990 occupations ranked according to occupational mean wages: at the top end was professionals followed by manager; associate professional; administrative-clerical; skilled trades; process and plant operatives; personal and protective; sales; other elementary. An upward move was set to 1 if any occupation at age 42 was a higher level occupation then their occupation at age 33 and a downward move scored 1 if their occupation at age 42 was a lower level occupation compared to their occupation at age 33. Thus the omitted reference group is the group who stayed in the 
same occupation and did not change their job. This does not fully capture employer change versus internal jobs changing, but it is a reasonable approximation. It has the added benefit of allowing us to incorporate the direction of occupational change.

On the home-related variables that may have changed over the period, we included dummies to capture changes in partner status and the addition of a new birth. Several other variables were also tried but discarded because of their lack of significance. ${ }^{4}$

All models were estimated using OLS regression. In the first instance models were run using the combined sample of men and women, using a dummy indicator to capture gender differences in the intercept. We then estimated the models separately for men and women to allow for coefficients to vary by gender.

\section{Data}

The data we used to measure occupational wage mobility come from the employment histories of the 1958 British Birth Cohort members, the National Child Development Study (NCDS). NCDS is a nationally representative longitudinal survey of over 17,000 births in 1958 although there has been some drop out, to around 11,000 in 1991 and 2000. Hawkes and Plewis's (2006) examination of attrition and non-response in the National Child Development Study found few significant predictors of attrition. This supports the view that the data are still reasonably representative of this population.

NCDS contains detailed employment, occupational and education histories for its members up to age 42 , at the time of writing this paper. Information about the wages of the employed and their job tenure were only available as concurrent data about jobs held at the survey sweeps, ages 42, 33 and 23. For the age 42 contact/interview, NCDS data achieved 11,419 interviews, 5624 with cohort men and 5795 with the women. The cohort members who gave complete information about their weekly working hours and earnings is less than those who were interviewed at both sweeps of NCDS partly because these data were only available for those employed at the interview, but also because earnings data, not uncommonly, had a higher item non-response than most other questions in the interview. In addition, we decided to focus on those employed full time both at age 33 and at age 42, a sample of 3558 full-time employees, 2606 men and 952 women, with full information on all other variables entered. All wages have been adjusted to reflect inflation changes, all being deflated or inflated to year 2000 values. 
These men and women, employed full time at both 33 and 42 varied from the rest of the interviewed sample at age 42 in terms of their qualifications, partnership status and family at age 42. Both men and women in our sample were more highly educated than those who were not working full time at this point, and women were more highly educated than the men; 34.0 per cent of the men in our sample and 39.4 per cent of the women had a qualification at NVQ level 4 or above (degree level) by age 42 . Among those interviewed at age 42, but not in our sample, 20.4 per cent of the men and 21.8 per cent of the women had such degree level qualifications at this age. Men in our sample tended to be more likely to be partnered at age 42 $(83.2 \%)$ compared with men who were not in our sample (66.1\%), and than women in our sample $(67.7 \%)$ who were also less likely to be partnered than NCDS women age 42 who were not in our sample (83.6\%). Men in our sample $(63.9 \%)$ were more likely to have a dependent child than NCDS men out of our sample (52.4\%) and women in our sample were far less likely to have such a child (43.5\%) than NCDS women out of our sample $(82.7 \%)$ at age 42 . Qualifications, partnership status and having a dependent child appear to be associated with the selection of men and women into this sample, with opposite effects for men and women in the case of family status. Dependent children are particularly uncommon among women employed full-time at both 33 and 42 .

The majority of our sample, working full time at 33 and 42 , are men (73\%). The women are a select group who should be best placed to take advantage of equal pay policy. In focusing on women employed full time at two points in time, we are removing some of the normal variation that occurs in women's wages. Many British women work part time when they have children, and move in and out of the labour market generating an intermittent employment career. Those who were working full time in their thirties are likely to be at the top end of the employment attachment spectrum, working continuously. They will not all be committed high-flyer career women depicted as having higher qualifications and having delayed childbearing, if any, into their thirties. However, the high flyers will be in this group, along with others who are working full time out of financial necessity, and possibly some mothers who had their children early and had returned to full-time employment.

For the sample who were working full time both at age 33 and age 42, women's raw mean hourly wage rate at age 33 was $£ 8.47$ per hour compared with a men's wage rate of $£ 10.10$ at the same age and time. By age 42, on an adjusted basis, women's hourly wage rate had 
increased to $£ 9.84$, a 16.2 per cent rise, and men's rates to $£ 12.36$, a 22.4 per cent rise. Thus controlled only for working full time, the female to male ratio for this group started out at 83.9 per cent but declined by age 42 to 79.6 per cent, a fall of 4.3 percentage points over this 9 year period in mid-life.

The means of our dependent wage growth variables are geometric means; these suggest, unlike the arithmetic means cited above, that there is little difference between men's and women's wage growth, at the mean, over the period, 12 compared with 13 per cent. However, a plot of the ratio of hourly wages at age 42 over age 33 shows that people with high salaries are commandeering disproportionate percentage pay rises over the 9-year period, up to four times bigger than those in lower earnings. These figures confirm earlier findings of Arulampalam et al (2005).

\section{Results - wage differences age 33 to $\mathbf{4 2}$}

The regression results modeling the wage difference for the pooled sample of all men and women are displayed in Table 1. The $\mathrm{R}$ square values are very low in these models because of the format of the wage growth dependent variable, as the difference of two log wages. This has eliminated much of the variation and between individuals' wages. When an alternative approach was adopted with the same set of independent variables, much better $\mathrm{R}$ square values were obtained, but the significance of the coefficients was largely unchanged. ${ }^{5}$ Men benefited from being over-represented in the two occupation categories with the most wage growth (Managers and Senior officials and Associate Professionals and technical). The male advantage when only occupation dummies were included in the model, declined to just over 3 per cent higher growth. This unexplained male advantage declined to zero when measures of changes in occupational status are entered as a second block of variables and stayed insignificantly different from zero as the human capital and demographic variables were added. Nearly all occupations had positive coefficients compared with the reference group, elementary occupations, although only managers, associate professionals and administrative occupations had a significant coefficient at 95 per cent level of confidence. Being in a managerial occupation at age 33 was associated with an increase of approximately 11 per cent wage growth over the next 9 years where the associate professional, and administrative occupations had wage growth coefficients of between 8 and 9 per cent. Professional jobs had a significant coefficient only at the 90 per cent level of confidence and had wage growth of approximately 7 per cent. 
The inclusion of occupation changes added to the explanation of wage growth and indeed reveals how the wage gains were achieved, or not, but they were at surprisingly similar levels for the men and women in this sample. For example 18.3 per cent of the men versus 18.7 per cent of the women experienced a downward job change, and 27 per cent of each experienced an upward change. Note that the women in this sample are selected on high labour force attachment. Changing occupation between 33 and 42 was significant when it was associated with downward occupational mobility, reducing wage growth by approximately 7 per cent in the total sample, but not significant when associated with upward occupational mobility. But the promotion element of these job changes was not associated significantly with wage growth, neither was job change without occupational change significant.

These results differ somewhat from earlier findings where it was possible to distinguish more accurately between intra or inter-employer moves. Working in a male-dominated occupation, as did 71 per cent of men and only 17 per cent of women, generated an average wage growth of 9 per cent, (11\% for those women in these jobs and 6\% for men). Working in an integrated occupation by age 42 (23\% of men and $34 \%$ of women) also brought significantly higher wage growth (5\% premium on average but $7 \%$ for women) than working in feminized occupations ( $49 \%$ of women and $23 \%$ of men). As found in many other studies, occupational segregation, and particularly women working in female dominated workplaces, is an important element of women's lower wages in comparison with men. The importance to women's wages of this aspect of their work is reinforced in the separate gender models described below.

Changes in human capital were also significant. Experiencing work-related training of 3 or more days (which affected approximately the same proportions of men and women) gave a significant 3 per cent boost to wages, although gaining a new qualification, more likely for the women than men, did not have any effect. Also having had some disruption to employment was associated with a lower wage growth in comparison with uninterrupted employment, approximately 10 per cent lower for one period out of work, and 19 per cent lower for two or more periods out of work. Working part time over the period, contrary to expectation, did not significantly depress wage growth on average. In this sample of men and women, work interruptions were hardly more likely for women than men, but the latter were more likely to have had occasional spells of parttime work. 
In terms of home-related factors, men in this sample were more likely to have partners and children, women were more likely to have experienced partnership change. In all cases, none were significantly associated with wage growth in this pooled model of women and men, given that occupational and work history terms are also included.

Allowing the coefficients to vary by gender in Table 1 (columns 2 and 3) did reveal some differences in the coefficients between men and women and in the explanatory power of the models at the different stages. The relative contributions of different blocks of variables to the explanation in the model varied by gender. Occupations and occupational change added most to the explanation of women's wage growth. Human capital added most to the explanation of men's wage growth although less to women's wage growth. Home-related factors added hardly anything to explanations of either men's or women's wage growth.

It is notable that the two top occupations were associated with significant wage growth for men but not for women. Male managers and professionals had higher wage growth by 11 per cent for managers and 9 per cent for professionals. These two occupations, where these men were more likely than these women to be employed, were important to understanding men's higher wage growth over this period. Downward occupational mobility over the period significantly reduced wage growth for men, by 6 per cent, and for women, by a higher percentage, 9 per cent. Upward occupational mobility and job change without an occupation change were not significant for men or women. Being in a male-dominated occupation, or an integrated occupation gave a significantly larger wage growth to women of 11 per cent for working in male dominated, and 7 per cent in integrated occupations, but no significant advantage to men. This could be because men who work in female dominated occupations can do very well, often being promoted to a greater degree over the women who work there (Simpson, 2004).

The addition of human capital measures mostly worked in the same direction for men and women. Having been out of the labour market once was associated with lower wage growth, 10 per cent for men, and 8 per cent for women. Two or more periods out of work reduced wage growth by 24 per cent for men but only 7 per cent for women, although on the margins of significance. This gender difference is consistent with women choosing occupations that do not penalize women so much for periods out of the labour market. Unlike in the pooled sample, having worked part time had a significant negative effect on women's wage growth, although it did not have any significant effect for men. However, in the separate samples, only men's wages benefited from having training. 
For men, having a limiting long standing illness was associated with approximately 4 per cent significantly lower wage growth, but not for women. It is possible that the often heavier physical demands of jobs held by men are harder to fulfill alongside having a longstanding illness than the lighter demands and expectations of many jobs held by women. The final addition of variables on family brought relatively little to the explanation of wage growth. Having a dependent child at age 33 and a full-time job at both 33 and 42 was associated with a significantly higher wage growth for women, by 6 per cent, but was not significant for men. This may reflect the group of women who have had their children early and whose wages are catching up on return to the labour market, or the motivations of select groups who need to work full time out of serious financial necessity or out of commitment to a career. Similarly, having lost a partner between ages 33 and 42 was associated with a positive effect on women's but not men's wage growth. Having another child between age 33 and 42, having a partner at age 33, or changing one's partner by age 42 were not significantly associated with wage growth for either men or women. Family and partnership made little difference, therefore, to wage growth. However, overall, these findings point to the selectivity of the sample and late childbearing for explaining the demographic effects, rather than there being a direct beneficial effect of motherhood on pay of a child in the thirties.

\section{Conclusions}

In this paper we have examined wage change between age 33 and 42 of the group of men and women selected because they were the closest comparators in their labour market experience, albeit men still starting out at age 33 having a wage advantage, despite the fact that these women were more highly educated than the men. Our analyses of their wage growth suggested the occupations held by these men and women and gender occupational segregation were important work-related explanations of wage growth. Men's wages grew most in the top occupations, where they were relatively more numerous and where those women who were employed received only average wage growth. Where women were in male dominated or integrated occupations they got an additional boost to their wage growth that men in these occupations did not receive. However, women's wages tended to grow more slowly over the period than men's wages because they were located disproportionately in feminised jobs which experienced slower wage growth. Downward occupational mobility was associated with lower wage growth but affected an equal proportion of men and women, although women were slightly more disadvantaged than men by the effects of downward occupational mobility. 
Opportunities for upward career paths to contribute to wage growth did not vary by gender. However, we need to note that the occupation groupings we considered were large and highly aggregated and will tend to underestimate the full extent of occupational mobility. Changes in human capital over the thirties were also found to be important, more for men than for women, but not dominating the explanation of wage growth. Periods of part-time employment penalised women but not men. However, periods of out of employment or ill health penalized men more than women. On the home-related factors, we found no evidence that the women's pay in this group was lagging behind men's because of domestic responsibilities, although domestic considerations undoubtedly play a part in determining the pay of women more peripheral to the labour market than this group of continuous full-time workers and may have affected these women before they reached age 33. Factors within the workplace, rather than the home, occupational choice and gender occupational segregation were generating the gender bias to wage growth as these people born in 1958 moved through the middle of life course.

We need to recognize that this full-time employed subset of the 1958 birth cohort are a particular group of workers whose experiences will not generalize to the whole population in the $21^{\text {st }}$ century. However, we can consider the question: If these are the gendered experiences of those born in 1958, what should we expect subsequent generations to experience, given that women of subsequent generations have both higher amounts of education and work experience? Future generations of women are likely to reach age 33 with wage rates closer to those of men than those born in 1958. But for their wage growth to match that of men's, they will have to break into male-dominated occupations to a much larger extent than was the case in the 1958 cohort of women. In addition, equal pay for equal value comparisons, job reevaluations, and pay audits will all have to become much more the norm for gender wage equality to be achieved.

\section{References}

Akerloff, G. (1998) 'Men without children', Economic Journal, 108, pp.257-309.

Anderson, T. Forth, J. Metcalf, H. and Kirby, S. (2001) The Gender Pay Gap. Report to the Women and Equality Unit, London: Women and Equality Unit, DTI.

Arulampalan, W. Booth, A.L. and Bryan, M.L. (2006) 'Is there a glass ceiling over Europe? Exploring the gender pay gap across the wages distribution', Industrial and Labor Relations Review, 60 (2), pp. 
Becker, G. (1975) Human Capital, second edition, Boston: National Bureau of Economic Research.

Blackaby, D, Booth, A. and Frank, J (2005) 'Outside Offers and the Gender Pay Gap: Empirical Evidence from the UK Academic Labour Market', Economic Journal, 115, F81-F107,

Booth, A. and Francesconi, M. (1999) 'Job mobility in 1990s Britain: Does gender matter? Research in Labor Economics, 19, pp.173-89.

Booth, A., Francesconi, M. and Garcia-Serrano, (1999) 'Job tenure and job mobility', Industrial and Labor Relations Review, 53(1) pp.43-70.

Booth, A., Francesconi, M. and Frank, J. (2003) 'A sticky floors model of promotion and pay and gender', European Economic Review, 47 (2), pp.99-126.

Crompton,R. and Sanderson,K. (1990) Gendered jobs and social change, London: Unwin Hyman.

Davies, H. and Peronaci, R. (1997) 'Male Wages and Living Arrangements', Birkbeck College Discussion Paper in Economics 5/97.

Dex, S. (1985) The Sexual Division of Work, Brighton: Wheatsheaf.

Dex, S. (2003) Families and work in the $21^{\text {st }}$ century, York: Joseph Rowntree Foundation.

Ermisch, J. and Wright, R. (1993) 'Wage offers and full-time and part-time employment of British Women', Journal of Human Resources, 28, pp.111-133.

Equal Pay Task Force (2001) Just Pay. Manchester: Equal Opportunities Commission.

Francesconi, M. (2001) 'The determinants and consequences of promotions in Britain', Oxford Bulletin of Economics and Statistics, 63 (3) pp.279-310.

Gershuny,J. (2000) Changing Times: Work and Leisure in postindustrial society, Oxford: Oxford University Press.

Grant, L, Yeandle, S and Buckner, L (2005) Working below potential: women and. part-time work. Manchester: EOC Working Paper Series No. 40. Equal Opportunities Commission.

Hakim, C. (1998) Social Change and Innovation in the Labour Market, Oxford, Oxford University Press

Harper, B. (1995) 'Male occupational mobility in Britain', Oxford Bulletin of Economics and Statistics, 57 (3), pp.349-69.

Hawkes, D. and Plewis, I. (2006) "Modelling Non-Response in the National Child Development Study", Journal of the Royal Statistical Society, Series A.

Joshi, H. (2005) 'Gender and Pay: some more equal than others' in A. Heath, J. Ermisch and D. Gallie (eds) Understanding Social Change. British Academy Centenary Volume, Oxford: Oxford University Press, pp. $151-185$. 
Joshi, H., Makepeace, G. and Dolton, P (2007 forthcoming) 'More or less unequal? Evidence on the pay of men and women from the British Birth Cohort Studies', Gender, Work and Organization.

Joshi, H. and Paci, P. (1998) Unequal Pay for women and men: evidence form the British Birth Cohort Studies. Cambridge, Mass: MIT Press.

Joshi, H., Paci, P. and Waldfogel, J. (1999) 'The Wages of Motherhood: better or worse?' Cambridge Journal of Economics, 23, 5, 543-564.

Kingsmill, D. (2001) Women's Employment and Pay. London: Cabinet Office and DTI, Available online at http://www.kingsmillreview.gov.uk/ Last consulted 25 September 2006.

Makepeace, G., Dolton, P. and Joshi, H. (2004) Gender earnings differentials across individuals over time in British Cohort Studies, 1991 and 2000. International Journal of Manpower. Vol 25 no $3 / 4,251-263$.

Manning, A. (1996) 'The Equal Pay Act as an experiment to theories of the labour market', Economica, 663: pp.191-222.

Manning, A. and Petrongolo,B. (2004) The part time pay penalty, Report to the Women and Equality Unit, London: Women and Equality Unit, DTI.

Manning, A. and Swaffield, J. (2005) 'The Gender Gap in Early-Career Wage Growth'. CEP Discussion Paper 0700, London School of Economics, http://econ.Ise.ac.uk/staff/amanning/work/gender.html

Millward, N. and Woodland, S. (1995) Gender Segregation and male/female wage differentials, in Humphries, J. and Rubery, J. (eds.) pp. 221-244.

Mincer,J. (1974) Schooling, Experience and Earnings, New York: Columbia University Press.

Mincer, J.and Polachek, S. (1974) 'Family investments in human capital: earnings of women', Journal of Political Economy, Vol.82 (2) pp.

Paci, P. Joshi, H. and Makepeace, G. (1995) 'Pay gaps facing men and women born in 1958: differences within the labour market' in Humphries, J. and Rubery, J. (eds) The Economics of Equal Opportunity, Manchester: Equal Opportunities Commission, 87-112.

Purcell,K. and Elias,P. (2008 forthcoming) 'Achieving Equality in the Knowledge Economy', in Scott,J. Dex,S and Joshi,H. (eds) (2008 forthcoming), Women and Employment: Changing Lives and New Challenges, Cheltenham: Edward Elgar.

Sicherman,N. and Galor,O. (1990) 'A theory of career mobility', Journal of Political Economy, Vol.98, pp.169-92.

Simpson,R. (2004) 'Masculinity at work: The experience of men in female dominated occupations', in Work Employment and Society, 18 (2) 349-68.

Women and Work Commission (2006) Shaping a Fairer Future. London: Women and Equality Unit, Department of Trade and Industry. 
Wright, R.E. and Ermisch, J.F. (1991) Gender discrimination in the British labour market: a reassessment. Economic Journal, 101,406, 508-52.

Zabalza, A. and Arrufat (1985) 'The extent of sex discrimination in Great Britain', in Zabalza, A and Zannatos, Z. (eds) Women and Equal Pay: the Effect of Legislation on Female Employment and Wages in Britain Cambridge: Cambridge University Press. 
Table 1: Wage differences for men and women from age 33 to age 42

\begin{tabular}{|c|c|c|c|}
\hline \multirow{3}{*}{$\begin{array}{c}\text { Regression dependent variable is } \\
\text { log of wage growth from age } 33 \text { to } \\
\text { age } 42\end{array}$} & \multirow{3}{*}{$\frac{\text { Men + Women }}{\text { Sample }}$} & \multirow[b]{2}{*}{ Men } & \multirow[b]{2}{*}{ Women } \\
\hline & & & \\
\hline & & Sample & Sample \\
\hline Constant & 0.042 & 0.086 & 0.006 \\
\hline Male & -0.009 & & \\
\hline \multicolumn{4}{|l|}{ Occupation at age 33} \\
\hline Managers and Senior Officials & $0.105^{*}$ & $0.107^{*}$ & 0.065 \\
\hline Professional & $0.073+$ & $0.092^{*}$ & -0.014 \\
\hline Associate Professional and technical & $0.080^{*}$ & 0.059 & 0.106 \\
\hline Administrative and secretarial & $0.092^{*}$ & 0.048 & 0.101 \\
\hline Skilled Trades & 0.011 & 0.005 & 0.028 \\
\hline Personal service & 0.022 & -0.007 & 0.057 \\
\hline Sales and Customer service & 0.053 & 0.017 & 0.120 \\
\hline Process, plant and machine operatives & -0.013 & -0.008 & -0.082 \\
\hline \multirow{2}{*}{\multicolumn{4}{|c|}{$\begin{array}{l}\text { Reference category = Elementary Occupation } \\
\text { Change in occupation from age } 33 \text { to } \\
\text { age } 42\end{array}$}} \\
\hline & & & \\
\hline Upward Mobility & -0.003 & -0.014 & 0.032 \\
\hline Downward Mobility & $-0.067^{*}$ & $-0.063^{*}$ & $-0.087^{*}$ \\
\hline \multicolumn{4}{|l|}{ Reference category $=$ No change } \\
\hline Had any change in job but not occupation level & 0.024 & 0.015 & 0.048 \\
\hline Male Dominated Occupation & $0.089^{*}$ & 0.056 & $0.112^{*}$ \\
\hline Integrated Occupation & $0.045^{*}$ & 0.005 & $0.069^{*}$ \\
\hline \multicolumn{4}{|l|}{$\begin{array}{c}\text { Reference category }=\text { Female dominated } \\
\text { occupation }\end{array}$} \\
\hline \multicolumn{4}{|l|}{$\begin{array}{l}\text { Human capital change from age } 32 \text { to } \\
\text { age } 42\end{array}$} \\
\hline $\begin{array}{l}\text { Done any work related training for } 3 \text { or more days } \\
\text { aged } 42\end{array}$ & $0.028^{*}$ & $0.032^{*}$ & 0.023 \\
\hline Worked Part Time from age 33 to age 42 & -0.026 & 0.050 & $-0.086^{*}$ \\
\hline $\begin{array}{l}\text { Experienced one period of non-working between } \\
\text { age } 33 \text { and age } 42\end{array}$ & $-0.100^{*}$ & $-0.103^{*}$ & $-0.079^{*}$ \\
\hline $\begin{array}{l}\text { Experienced two periods of non-working between } \\
\text { age } 33 \text { and age } 42\end{array}$ & $-0.192^{*}$ & $-0.244^{*}$ & $-0.072+$ \\
\hline \multicolumn{4}{|l|}{$\begin{array}{r}\text { Reference category = Continuously worked from } \\
\text { age } 33 \text { to age } 42\end{array}$} \\
\hline New qualification by age 42 & 0.019 & 0.026 & 0.001 \\
\hline \multicolumn{4}{|l|}{ Demographic circumstances } \\
\hline Had partner at 33 & -0.020 & 0.003 & -0.047 \\
\hline Had dependant child at age 33 & 0.008 & -0.025 & $0.064^{*}$ \\
\hline $\begin{array}{l}\text { Had no partner at age } 33 \text { and had a partner by } \\
\text { age } 42\end{array}$ & -0.026 & -0.051 & 0.030 \\
\hline Had a partner at age 33 and no partner at age 42 & -0.004 & -0.040 & $0.062+$ \\
\hline Had more children by age 42 & 0.010 & 0.003 & 0.018 \\
\hline Had longstanding limiting illness at age 42 & $-0.026+$ & $-0.043^{*}$ & 0.012 \\
\hline Sample Size & 3558 & 2608 & 952 \\
\hline R Squared & 0.032 & 0.035 & 0.077 \\
\hline F stat, $p$ value & $4.64 \quad \mathrm{P}<0.000$ & $3.95 \quad P<0.000$ & $3.19 \quad \mathrm{P}<0.000$ \\
\hline
\end{tabular}

Note: * represents $p=0.05+$ represents $p=0.10$ level of confidence 


\section{ACKNOWLEDGEMENTS}

We acknowledge funding for the research contained in this paper from the ESRC grant reference RES-225-25-2001, as part of the Priority Gender Network, GeNet, coordinated from Cambridge University. We also wish to thank Dr. Jane Elliott for providing us with ready made indicators of the occupational segregation of 1990 occupation groups at the 3- digit level, Dr. Roger Sewell for varied inputs, and 3 anonymous referees.

\section{Notes}


${ }^{1}$ This was based on the relative rates of remuneration for abilities, qualifications and employment experience estimated in models fitted to all full-time workers. The mean of the index of unequal treatment for 989 women who were full-time employees at two surveys, is $15.7 \%$ at age 33 and $20.0 \%$ at 42 , an increase of over $4 \%$, for all women.

${ }^{2}$ Education qualifications were also entered into the model, but overlapped to a considerable extent with the occupation indicators, reducing their significance while not adding anything to the model. A number of studies have argued that education affects occupation mobility, with higher mobility and promotion resulting from higher education (Harper, 1995; Sicherman and Galor, 1990). However, these earlier studies did not also include occupations. Occupations clearly encompass educational qualifications to a large extent, and are more closely related to the alternative career paths in or between organisations. Highest education dummies were also tried in the model instead of occupations, but did not perform as well and so were dropped from the final versions.

${ }^{3}$ Occupations were classified as mainly male or mainly female if they had a $70 \%$ share or more male (or female) employees in that occupation. Integrated occupations were the rest.

${ }^{4}$ Dummy variables were used to capture excessively large (or small) gaps between the two interviews which may have increased (or reduced) the length of the growth period. Dummies to recognise plus or minus two standard deviations from the mean inter-interview gap and change between low and high wage regions from 33 to 42 were not significant. We also included attitude measures from age 33 NCDS, but the missing values on these variables substantially reduced our sample size, by several hundred women and the same for men, so we decided to drop these variables.

${ }^{5}$ The alternative approach was to regress log hourly wage at age 42 against the same set of independent variables but including log hourly wage at age 33 as an additional independent variable. The $R$ square value for the sample of men and women, including a dummy variable for gender, was 0.47 from this alternative approach compared with 0.032 using the difference of two logs approach to wage growth as reported in the paper in Table 1. 